\title{
Maintaining the Flow: medical challenges to breastfeeding and 'risky' bodies in Mexico
}

DOI:

10.1111/maq.12511

\section{Document Version}

Accepted author manuscript

Link to publication record in Manchester Research Explorer

\section{Citation for published version (APA):}

Murray De Lopez, J. (2019). Maintaining the Flow: medical challenges to breastfeeding and 'risky' bodies in Mexico. Medical Anthropology Quarterly. https://doi.org/10.1111/maq.12511

\section{Published in:}

Medical Anthropology Quarterly

\section{Citing this paper}

Please note that where the full-text provided on Manchester Research Explorer is the Author Accepted Manuscript or Proof version this may differ from the final Published version. If citing, it is advised that you check and use the publisher's definitive version.

\section{General rights}

Copyright and moral rights for the publications made accessible in the Research Explorer are retained by the authors and/or other copyright owners and it is a condition of accessing publications that users recognise and abide by the legal requirements associated with these rights.

\section{Takedown policy}

If you believe that this document breaches copyright please refer to the University of Manchester's Takedown Procedures [http://man.ac.uk/04Y6Bo] or contact uml.scholarlycommunications@manchester.ac.uk providing relevant details, so we can investigate your claim.

\section{OPEN ACCESS}




\section{Medical Anthropology Quarterly}

Maintaining the Flow: medical challenges to breastfeeding and 'risky' bodies in Mexico

\begin{tabular}{|r|l|}
\hline Journal: & Medical Anthropology Quarterly \\
\hline Manuscript ID & MAQ-Jul-2018-OA-5037.R2 \\
\hline Manuscript Type: & Original Article \\
\hline \multicolumn{2}{l}{} \\
\hline
\end{tabular}

SCHOLARONE $^{\text {m }}$

Manuscripts 


\begin{abstract}
In this article, I discuss a case study from Southeast Mexico that highlights conflicting ideas regarding what constitutes risk and illness in the context of breastfeeding and postpartum practices. On the one hand, doctor's indeterminate and conflicting diagnoses about mother's milk as a source of pollution is revealed as an act of moral pathology that frames young mothers as high risk. On the other hand, milk pollution is understood by women as an unwelcome yet temporary interruption that can be remedied through non-allopathic intervention. As such, women can exert collective agency to overcome medicalised barriers to early breastfeeding and maintain established nurturing practices.
\end{abstract}

Keywords: breastfeeding; postpartum; pollution; Mexico; risk 


\section{Introduction:}

It is widely recognised that exclusive breastfeeding is one of the most cost-effective strategies for improving infant mortality and many aspects of postpartum recuperation in all incomelevel settings. In low- to middle-income countries (LMICs) such as Mexico, exclusive breastfeeding in the first six months of life has been shown to significantly improve infant morbidity and mortality, although less is known about health benefits for the mother in the long-term (González de Cosio et al., 2013; Victora 2016). Paradoxically, as the scientific evidence base on the benefits and content of mothers' milk gains increasing attention and funding, the prevalence and duration of this practice remain below optimum levels worldwide. Research attributes structural and societal barriers to breastfeeding including dominant medical models of childbearing, changes to labour patterns, gender inequalities, sociocultural attitudes, lack of regulation of the formula milk industry, and increased perceptions of insufficient milk production (Rollins et al., 2016; Sacco et al., 2006; McFadden et al., 2016). In LMICs, the additional charge of maternal depletion - a breakdown in the mother's health leading to an inability to produce milk or breastfeed - has been an enduring narrative since the 1970s (Maher 1992; Scheper-Hughes 1993). ${ }^{\mathrm{i}}$ The medicalised terminology of maternal depletion transforms breastfeeding into a policy issue based upon nutrition, human rights, and reproductive governance, often foregrounding the infant's needs over those of the mother. As such, maternal depletion frames women as (un)healthy subjects and endows them with moral obligations as caregivers, while at the same time presenting them as lacking agency to challenge structural and societal barriers alone.

In Mexico, exclusive breastfeeding during the postpartum period has been on a gradual decline for decades (González de Cosio 2013; Pérez-Escamilla 2003). Although we can question whether exclusive breastfeeding in the first six months has ever been the norm among the general population, this reported decline is consistent with a global narrative of increased urbanization and broad-scale economic changes that characterised LMIC development in the previous and current centuries. The Mexican sustainable development agenda reflects the universal shift to prioritise breastfeeding as a human rights and food security issue. Alongside the government's commitment to the global sustainability agenda, the Mexican National Development Plan (Plan Nacional de Desarrollo 2013-2018) incorporates the Programme for Targeted Maternal and Perinatal Action (El Programa de Acción Especifico de Salud Materna y Perinatal or PAE SMP). Among other issues, the PAE SMP aims to update pre- and postnatal care and support the implementation of care delivery 
units focussed on intercultural needs and preferences. In 2014, as a follow-up to the PAE SMP, the government launched the National Breastfeeding Strategy (Estrategia Nacional de la Lactancia Materna 2014-2018). Informed by data from the 2012 National Health and Nutrition Survey, the breastfeeding strategy stated that 'until now we have not had a successful campaign that has influenced the general population's perception of natural feeding, not one that includes adequate information' (Secretaria de Salud 2014:11 my emphasis). The National Breastfeeding Strategy also acknowledges that medical personnel are often principal actors in determining breastfeeding practices in the first 36 months postpartum. Informed by a robust evidence base, the National Breastfeeding strategy acknowledges that the medical habit of 'prescribing' formula to supplement or replace mothers' milk is a significant barrier to exclusive breastfeeding in the first six months.

Despite this recognition in policy, there remains only sparse qualitative data on the medical reasons given to Mexican women as to why they should stop breastfeeding, and furthermore how medical reasoning may reflect other social factors that facilitate or hamper breastfeeding in both the short and long-term. Even less is known about what women do once they leave the hospital or clinic and how they interpret the instructions given to them against existing expertise and intergenerational knowledge on childrearing. In this article, I discuss the case of a new mother, Carlita Gomez to demonstrate how women in a low-income barrio understand breastfeeding to be an essential part of relationship-building and person-making that goes beyond the service of infant nutrition. When a crisis arises, Carlita and her relatives exploit the doctor's indeterminate and contradictory diagnosis about Carlita's milk as a source of contamination in order to prioritise their own treatment. In doing so, these women maintain established postpartum practices even while simultaneously appearing to comply with the doctor's orders. Accordingly, they adapt established nurturing practices to overcome overtly medicalized challenges to breastfeeding.

This study contributes to the growing body of anthropological work termed appropriately by Aunchalee Palmquist in her 2014 blog post as 'anthrolactology'. This new generation of ethnography-driven cross-disciplinary research builds on previous anthropological work exploring the various ways in which breastfeeding can be understood as custom as well as biocultural instinct (Maher 1995; Van Esterik 1988, 1989; Dettwyler 1988; Mead 1970). Owing to a revitalisation of the subject area in recent years, there now exists detailed ethnography of feeding practices and politics in high-income countries (Faircloth 2013; Tomori 2014;); milk banking and sharing (Soler 2017; Falls 2017; Reyes-Foster et al., 2015; 
Cevese 2015; Palmquist and Doehler 2014); edited collections covering milk meanings and morality in the Global North and South (Cassidy and El Tom 2015; Tomori, Palmquist and Quinn 2017); mothers' milk as a concern for gender inequality, sustainable futures, and food insecurity (Ausona Bieto et al., 2017; Falls 2017; Van Esterik and O'Connor 2017; Maher 2015); and biomedical regulation of population groups (Van Hollen 2011; Mathews 2015). More specific to the Mexican context, interdisciplinary research has focussed predominantly on the effectiveness of policy and public health interventions (Pérez-Escamilla 2003; Safon et al., 2018; Colombara et al., 2015); attitudes and knowledge of health professionals (de la Rosa and Herández 2000); barrier perceptions of low-income women (Guerrero et al., 1999; Sacco et al., 2006; Pérez-Escamilla et al., 1993; Bueno-Gutierrez and Chantry 2015; Navarro Estrella et al., 2003); and most recently, the emergence of lactivism among the urban middleclass (Vidal 2017). When research questions focus on the barriers to exclusive breastfeeding, studies tend to de-center women's collective expertise and underplay the role of local midwives. This article is one attempt to readdress this lack of attention to existing expertise among women and to refocus attention to the ways in which nutrition and medicine are intertwined by both intergenerational relationships and the breast. It enables us to ask of global health praxis: what can be learned from existing knowledge, rather than what can be imposed?

This study also contributes to anthropological work on the temporality of pollution and intersecting meanings of mothers' milk as a danger to health (Farmer 1998; Bandyopadhyay 2009; Scheper-Hughes 1985,1993; Valeri 2000; Gottlieb 1989; Douglas 2002(1966)) and connects this phenomenon to the growing body of work on gendered morality, reproductive health, and risky bodies in Mexico (Murray de López 2016;2018; forthcoming, Singer 2017; Santiago et al., 2018; Smith-Oka 2013; Carrillo and Bliss 2007; Gutmann 2009; Bringas et al., 2004; Castro 2004). Here, I connect ideas about pollution and risk via Mary Douglas' notion of risk (and danger) as a forensic resource (Douglas1990). According to Douglas there exist shared biosocial conventions in medicine, where risk acts as a forensic resource in proportioning blame for things that have gone wrong or for events that are unforeseen. In the case of Carlita, this is brought about by doctors' assumptions about a young mother from a low-income barrio who appears to have flouted the accepted medical norm that giving birth is safest in a hospital. In the following pages, I use Carlita's case to explore what happens when ideas about quality and contamination of bodily fluids are found simultaneously in both lay and medical reasoning, yet with very different ideas about temporality and risk. 
For the purpose of this paper I limit the postpartum period to the first two of three continuous phases described by Romano et al., (2010): the acute period, the first six to twelve hours after birth, the subacute period lasting two to six weeks and a final delayed period lasting up to six months. The first two phases orient us toward postpartum practices within a comparative biomedical framework that recognises both bodily transition and the healing that takes place within a specific timeframe. Acute and subacute phases are, in essence and in a temporal sense, comparable to the concept of the forty-day confinement commonly practiced in lowincome Catholic homes in Mexico. Although it is referred to locally as the cuarenta dias ${ }^{i i}$, depending upon the support network, labour patterns, and physiological healing, the period in practice can be anytime between two weeks to forty days of some form of isolated convalescence. It is during this confinement that new mothers are thought to physically and emotionally heal and establish feeding and their milk supply. My title Maintaining the Flow in this sense is twofold in that it refers to the facilitation of continuous breastfeeding in the acute and sub-acute period, and to capture the sense of fluidity at play within the ecosystemic nurturing model.

\section{Method and Fieldwork Enquires:}

The case example is taken from a broader study of maternal transition in a small city in the highlands of Chiapas, Southeast Mexico. I undertook fieldwork among low-to middle-income families over three months between 2010 and 2011, a subsequent nine months in 2013, and a further one month in 2015. In 2013, I was situated in a neighborhood on the outskirts of the city. Like many of the cities outlaying barrios, this city had grown as an overspill from the city's more traditional colonial-style neighborhoods. The overspill barrios are characterised by improvised infrastructures and multi-generational households that emerged from the days when the terrain was woodland and farmed land. Decades of fighting with the municipal government for basic services and land rights resulted in communities that prefer to govern themselves and that have a mistrust of what the state promises to provide. How this mistrust manifests in health-seeking behaviour among families in the barrio is distinct. Although many families now have access to mixed economy public and private healthcare, when it comes to maternal health, local midwives during pregnancy, post-partum, and homebirth remain the preferred option for most households. This is in stark contrast to other areas of the city and among the city's transient migrant populations, where midwives have a minor to non-existent role in deliveries. The prevalence of homebirths among families in this barrio 
guided my research toward the fluid and multi-dimensional environmental factors that render a woman vulnerable throughout her transition to motherhood.

In this article I employ the term eco-systemic model of nurture to bring together the multiple factors that contribute to nurture and care practices within a close-knit community or household. Taking an ecological approach allows us to examine the interplay among generational, situational, sociocultural and political factors that shape nurturing. Understood within an eco-systemic model these factors co-exist rather than merge. In developing this term, I take inspiration from Silvia Rivera Cusicanqui's (2012) notion of Ch'ixi where intersecting cultural factors may antagonize or complement each other on equal terms. As such, we can observe apparent contradictions as co-existing behaviours.

The almost complete institutionalisation of maternal health in Mexico over recent decades (estimated nationally as $94.4 \%$ of all registered births taking place in hospital), makes it an important country to study for links between the impact on changes in attitudes to birth and caregiving ethics. The south eastern state of Chiapas has the lowest number of institutional births and reportedly higher than national average rates of breastfeeding from birth to 12 months (ENSANUT 2013). The city in which my fieldwork took place is remarkable in this regard. Set at the foothills of the rural highlands, the local hospitals are a key transfer sight for high-risk pregnancies and obstetric emergencies from the outlying villages. All round levels of diet and nutrition are below national averages and mortality rates are high. The region is a target for the federal conditional cash transfer programme, PROSPERA, which includes maternal and infant health management at dedicated clinics as a condition of receiving welfare. While the high level of emergency transfers and 36.2\% caesarean section rate in public hospitals (Freyermuth et al., 2017) undoubtedly shapes doctors' attitudes to the risks associated with childbearing and more so the health profile of poor women, it does not necessarily reflect how pregnancy, birth, and early nurturing is happening across the city landscape.

The difficulty arising from the purely metric health profile gained from institutional reporting and household surveys is that it gives a very narrow perspective of a complex situation. With the government aiming to provide a $100 \%$ institutionally-managed birth profile, out-ofhospital birth simply does not fit in the current health system; and therefore, it becomes framed as being against the system and high risk. Homebirths and in-depth postpartum care metrics go unaccounted for, since at present there are no supported systems in place for 
recording detailed outcomes (Murray de López \& Alonso in press 2019). Although certified midwife-nurses and technical midwifes are recognised as practitioners in the public health sector, their actual role and responsibilities remain undefined (Atkin et al., 2015; Dixon 2015; Murray de López \& Alonso 2018). The registering and monitoring of traditional midwives in Chiapas is haphazard at best and does not represent the variation of maternal healthcareseeking behaviours prevalent among urban households (Murray de López 2015). These ambiguities matter when it comes to relationships between families, midwives and biomedical professionals.

\section{Meanings of Milk}

The Gomez family home is characteristic of most multi-generational households throughout the small city. The family members mostly have a modest income and although eligible for public health insurance, they have good access to credit and often prefer to use private services when necessary. At 16 years old, Carlita's pregnancy had not been planned. "Whether it's God's will or stupidity, it happened, and we'll love it all the same, every baby is a blessing," her grandma Doña Reina often repeated. Not many girls in this neighborhood stay in education beyond secondary school, most preferring to begin work in low-paid, lowskilled jobs in the city centre or to support mothers and grandmothers in the endless labour of running households and home-based businesses. If a girl becomes pregnant, she does not automatically move in with her boyfriend's family, unless she is rejected by her own family or through her own volition. Despite the preference for household and economic labour over education, early motherhood is more often than not an accident rather than an objective. Most young women are accustomed to looking after younger siblings, cousins, or nieces and nephews, and they are aware of the level of work involved in caregiving. When pregnancies occur, young women often adopt a fatalistic attitude closely followed by a narrative of acceptance and faith that all would work out in the end.

As it turned out, my own pregnancy and Carlita's coincided so that we were both due within a month of each other. This is partly how I came to know, and gain insight about Carlita's experiences. During our final trimester, I spent most afternoons chatting at the entrance to the Gomez family's plot of land. Positioned on the busy main road directly opposite my house, three crumbling concrete steps led up to a tatty wooden door frame that sat within a tall brick and adobe wall. Behind the wall, a number of small buildings housed three of Doña Reina's six children and their families. Doña Reina would sit perched on a three-legged stool in the 
wooden doorway, from where she could look out at the activity in the street. While her daughter-in-law, Doña Carla, and granddaughter, Carlita, sold fruit and vegetables from a small stall to the left of the steps, we would discuss how, where, and with whom we planned to give birth.

Although Carlita had been to regular prenatal check-ups at the local public hospital, as well as private appointments with an obstetrician and numerous ultrasounds, Carlita planned to give birth at home attended by the family midwife. Unlike births in the neighboring state capital, many women in the low-income neighborhoods of this city continue to give birth at home with a local midwife. "It's just the way we like to do things." Doña Carla explained to me "[birth] is safe at home, where you can be close to family." One afternoon in early June, after declining numerous offers from the obstetrician to be induced, Carlita went into labour naturally and within twenty-four hours had given birth at home. Attended to by the family midwife and her mother, Carlita's labour had gone without complications, and as I found out the following day, both mother and baby were in good health. They had left the house once within the next 48 hours to register the birth at the local maternity hospital, here her newborn baby girl had been examined and had received her first round of vaccinations.

I went to see Carlita and her newborn, Alison, approximately one week after she was born. That morning, she and her infant were being attended to by Doña Carla and her mother, and Carlita's sister-in-law, Dulce. A room had been set aside for the postpartum cuarenta dias that was normally used by Dulce, her husband, and their two-year old son. This was the room where Carlita had given birth just a few days earlier, where she had been surrounded by the same women who looked after her now. As I stepped into the dimly lit room, I could see Carlita sitting propped up in the bed, swamped underneath a dozen woollen blankets. She smiled and nodded hello. A large rebozo was wrapped around the new mother and baby while she breastfed, ensuring that the blanked bodies became fused together. She remained quiet whilst Doña Carla directed the conversation. "Look at hers," she said, chuckling and nodding in my direction as I sat feeding my own daughter. "Not like our little ones," she said, referring to my exposed breast. "You could feed all the babies around here with those! Do you have lots of milk?" She turned to her own mother who was sat to my left, "See mamá, they feed their babies like we do." The older woman turned to me and smiled, she reached over and adjusted by rebozo to cover both breast and baby. 
I answered Doña Carla, “Yes, I'm lucky I've always had good milk.” I looked across to Carlita who was watching us with amusement. "Has your milk come in yet?"

"I think so," she said quietly, "she's feeding quite a lot, so I suppose so."

"Yes, it's coming," interrupted Doña Carla. "The midwife gives her fennel tea and she also drinks plenty of oat milk that helps it come in."

Despite its continued prevalence in homes throughout Mexico, very little has been written about the cuarenta dias, its meaning in the broader construction of personhood and maternal identity, or how it is impacted upon by medicalised external forces. The type of caregiving that takes place during the cuarenta dias is as much about 'person-making' as it is about healing and nurture. Van Esterik describes this period as creating a 'social womb where the nurturing that turns the infant into a social and cultural being occurs' (2015: xvi). It can be argued that the cuarenta dias, as the social womb embodied, inseparably combining the process of maternal person-making and the infant who is coming into being. This 'biosocial package' highlights breastfeeding as a central 'biocultural activity, during which neonate and mother interact opportunistically and ritually, encapsulated within a historically constituted, custom-structured and symbolically weighty womb-like cultural whole...' (Van Esterik and O’Connor 2017:36).

During the cuarenta dias the health and nutrition focus of care are all important. The quality of milk is checked regularly by elder female relatives and family midwife Attempts are often made to maintain or improve the quality of milk by feeding the mother oat milk or atole (a drink made from maize). Different herbs such as fennel, spearmint, pine, and eucalyptus, either consumed as infusions or inhaled through steam baths, are also used to increase the flow of milk. The use of herbs and foods to help milk supply continues throughout the breastfeeding lifecycle but is most intense during the initial postpartum period. To be sure, the fact that great effort is made by families to ensure a peaceful and protected environment for mother and infant, including the use of herbs, suggests that a mother's milk is not always deemed of sufficient quality and strength alone for a healthy baby. Taking steps to augment her own capacities, a mother is quite dramatically nurtured by the community during this time. This period of time also enables an affirmation of the emotional connection and mutual reliance of family members as keys to successful recuperation. In this way, breastfeeding and the flow of milk are part of a comprehensive system of beliefs and practices that enable a fluid and seamless transition to motherhood during the nurturing period. 
I argue that maintaining this social womb requires collective action and expertise under pressure from external forces that may threaten it - forces that ironically are offered as biomedical forms of care. To see how these forms of care are transformed into threats to the social womb we must turn to an exploration of the ways that women like Carlita are transformed into various forms of biomedical 'risk'.

\section{Risk as a Forensic Resource}

Within two weeks, Carlita's cuarenta dias was interrupted by the sudden illness and hospitalisation of Alison. One afternoon she had begun with a fever succeeded by her coughing up what looked like a bloody mucus, in a panic the family called an ambulance and Carlita and Alison went accompanied by her parents to public hospital. During the time that they were in hospital, Alison's illness went without a clear diagnosis, and after four days in hospital and administration of antibiotics she was discharged. Carlita and her mother had permission to stay with Alison in the hospital during this time, but Carlita was not allowed to breastfeed or express her milk. Doña Carla later told me that two days after returning home Alison had begun with a fever again and this time the family took her to a private hospital in the city, still concerned that they had no clear diagnosis. This time Alison and Carlita stayed for 24 hours under observation and were then sent home. During both times in hospital, Carlita and her family were given various non-specific explanations from the emergency doctors and a paediatric consultant.

Shortly after the second hospitalisation, I sat with Doña Carla outside her house, and she told me the following: "[The doctor] says the baby has a stomach infection that went up to her head. We had only left the house with her once", she explained, "to get her checked and registered at the clinica." Many midwives working in the city barrios have not attended government training, are not registered with the state, and are unable to provide families with a birth registration certificate. To obtain a birth certificate under these circumstances, a family will take the newborn to a local clinic in the first few days following the birth, to ask a doctor to register it as a spontaneous homebirth. Doctors, in general, will accept the explanation, although they often use the opportunity to scold the family for being irresponsible and delaying coming to the hospital. The family will obtain the birth registration certificate upon completion of a newborn examination and first round of vaccines.

Over the course of several days, I learned more about the circumstances and explanations for Alison's mysterious decline in health. These details began to paint a picture of risk, or more 
specifically, of efforts to transform women like Carlita into a source of risk. The first doctors to assess baby Alison, when she was transferred by ambulance, claimed the illness was brought on by the infant not receiving all her vaccines at birth. I wanted further clarity on this, so I asked if she remembered which shots they gave her in those first few days after birth. Doña Carla thought for a moment and replied, "I don't know, all of them. I think. [The doctors] said it was our fault because we must have missed one that goes in the leg." As she said this, she pointed to her thigh.

"Do you remember what it is called?"

"No, it's just the shot that goes in the leg. I don't know what any of them are called," she said.

When the infant was first admitted, the emergency doctors were told that Alison had been born at home, and they took this opportunity to deliver a diatribe of blame, telling her that her family should be ashamed for having taken this risk. This assessment was displaced later, when Alison was admitted the second time. In the private hospital, the paediatrician told the family that the infection had not resulted from missing vaccines, but rather that it was passed to Alison through Carlita's milk. "She has colitis" Doña Carla told me. "[Carlita] suffered with it a lot as a teenager, and he said it will have made her milk infected". This time, blame was directed away from the family birth practices and towards Carlita's individual body, with the suggestion that her milk was 'infected' with her colitis. This doctor told Carlita to stop breastfeeding straight away and substitute with formula that he would prescribe. He explained that if she continued to breastfeed, then Alison was at risk of further illness. The notion that colitis can be passed from mother's milk to infant has absolutely no epidemiological basis, at most infection can be passed via a contaminated nipple, not the milk itself

The interesting thing is, Carlita's admonishment regarding her posing a risk to her infant by way of her own supposed history of colitis is not uncommon. The way in which colitis is used by doctors in Mexico to explain all varieties of bowel-, stomach-, or colon-related conditions makes it impossible to say whether Carlita's past diagnosis was a contagious form of the disease or not, let alone whether there was the near impossible risk of her contaminating her nipples with the disease and infecting the infant. Nevertheless, the perception on the part of the doctors who cared for Alison was that Carlita herself was a source of danger to her infant. As others have noted, medical professionals can regulate and control maternal bodies by 
'creating risk' in a variety of ways (MacKenzie and Van Teijlingen 2010). This approach to 'risk equating to danger' results in a complex series of decisions made by biomedical caregivers who feel the need to protect babies from the traditional behaviors of mothers like Carlita. That these equations of risk and danger are widespread and normative means that doctors will tend to err on the side of caution; and thus, a rare possibility becomes factual explanation and guide for medical advice and diagnosis.

The ways in which some health professionals framed Carlita as irresponsible or as a risk in her own right emerge within a political and biosocial context. Chiapas is among the country's five most marginalised regions. It has the highest recorded unemployment levels and the lowest educational attainment for girls in all the thirty-two federal states (OECD 2015). Access to public services throughout the state remains inadequate, and this is associated with much broader political economic and structural inequalities. This state has the second highest maternal mortality rate (68.1 per every 100,000 live births) and the highest national infant mortality rate (17.9 per every 1000 children under 5 years old). In addition, this region has the highest incidences of child marriage and adolescent pregnancy (along with its associated health risks). Premature marriage and parenthood are not restricted to rural populations; the most recent Mother's Index Study identified the low-income general population as equally at risk as the minority indigenous populations in towns and cities (Garita Edelen et al., 2016). As Douglas contests, the reality of the dangers of childbirth in a place like Chiapas legitimates for doctors, the high-risk factors involved in how and where women give birth. Yet, this 'argument is not about the reality of the dangers, but how they are politicized' (Douglas 1990:8).

In many ways, Carlita fits the profile of the 'at risk' population that health professionals are primed to look out for. However, these profiles overlook vast amounts of information about how young women actually give birth and are cared for in communities. Population surveybased studies overlook the relationships and networks of support that are available to many young women in multigenerational families. Thus, bleak demographics form local medical attitudes and make educated professionals nervous about women who are seen to be challenging authority by taking unnecessary risks, such as having sexual intercourse without contraception and giving birth at home. The confluence of care provision priorities coupled with profiling techniques that already cast young women like Carlita as an aberration of normative health behaviors led to a situation in which Carlita was treated as a risk by doctors and reproached for being the cause of Alison's illness. Her 'risk' to her own infant continued 
into and through the postpartum period. The way in which the biomedical approach to splitting the postpartum period into distinct phases, with separate predicted outcome risks for mother and infant, undermines the fluidity and blurring of time that occurs in the social womb eco-system. For families in the barrio, the idea of the cuarenta dias is a loose measurement if time within which healing of the mother-infant dyad does not follow a set path. It is simply understood to provide 'enough time' for transition to occur and healing to take place.

If we understand the production of a mother's milk and breastfeeding as part of human reproduction as a whole, it becomes clear how the same assumptions about pregnancy and birth as high risk (within a medicalised model) continue into the nurturing period. Herein, the postpartum body emerges as a source of conflict in terms of how it can simultaneously protect and endanger the newborn. What is understood to be contaminating poses a threat to the social order. This conflict is also prevalent in local biocultural understanding, where ideas about risk are not mutually exclusive but continuously intersecting. Emotion, temperature, diet, and illness (stomach upset, cold, pains) are all factors within the mother that can put an infant at risk during its first forty days of life. "Their lungs are not ready to breathe alone", Doña Reina, Carlita's grandmother, said when I asked her about what makes an infant vulnerable to its environment. In saying this, she evoked the idea that being swaddled to the mother's body during the forty-day confinement was supporting the infant to breathe, much as she had done in the womb. During the immediate postpartum period, mother and infant are understood by families to be a unit, and as such, the physiological and psychological connection must be protected from harm. Such local knowledge and beliefs are used by medical professionals and family members alike to intervene in and regulate postpartum bodies.

The flow of milk from one body to another provides doctors with tangible evidence of the intimate connection between mother and infant that (according to risk logic) has the potential to be harmful. Ultimately the cause of Alison's illness remains inconclusive, like much diagnostic work it is guess work, an act of deduction on part of the doctors. However, their deductions are not value free but based upon background assumptions they make about age, gender, class and homebirth. Due to her social position, Carlita is a suspicious subject for doctors, her body predetermined as dangerous. According to Douglas, within this risk concept we shift from a probability (harm potentiality) to a concrete prediction of danger. Risk serves the forensic need for accountability in modern global health culture. The 
vocabulary of risk invariably transforms local, family and community practices as part of a nexus which enables doctors to trace blame for illness back to its (uncertain) source.

\section{Contradictions and Collective Agency}

Once home from the second hospitalisation, Doña Carla sought advice from the midwife, who told them that Carlita should continue breastfeeding with the addition of fennel tea given to both mother and infant to help settle the stomach. Carlita and Alison eventually completed their cuarenta dias without further complications and continued to breastfeed for the following eight months without having to substitute with formula. On the subsequent occasions that they returned to the private clinic for check-ups, they chose not to explain that Carlita continued to breastfeed. "If the colitis affects the milk, then we will see to that in our own way", Doña Reina explained. "She has good milk, nice and thick, the baby will grow stronger with it than without it."

How families behave and when they seek support during pregnancy reveals much about their own models of risk. One might argue that the mother-baby unit was vulnerable to external forces that they perceived, folding advice for care into notions of the kinds of risk women are seeking to avoid. They balanced risk assessments offered by both public and private healthcare against competing and equally indeterminate notions of risk that were mitigated by community and forms of care offered in house.

The type of clinical decision-making that Carlita was exposed to is reflected in Mexico's national policy guidelines. The Mexican National Breastfeeding Strategy summary declares that conditions in public hospitals are not adequate to promote breastfeeding from birth, and they acknowledge doctors are often a prime cause of premature breastfeeding cessation. However, the evidence derived from the national health survey fails to investigate why this is the case or to question exactly what it is that doctors are doing to influence cessation of feeding. During fieldwork, I noted that before leaving hospital or during antenatal classes, women were often advised to wash their breasts and nipples prior to feeding an infant. The concern from health professionals giving out this information was that an unclean body could cause stomach infections in the infant or contaminate the milk. On occasions when babies were taken ill with stomach upsets or colic, women who came from families with generations of hospital births would comment on how the mother must not have "washed her breasts properly", therefore highlighting the apparent danger of the maternal body to the now separated infant being. The practice of washing breasts resembles the public health advice given to women regarding bottle feeding and home hygiene. Whilst there is some evidence to 
suggest that contamination of the nipple can be a source of infection for infants, the rhetoric about women as a source of risk went far beyond this issue. Indeed, women and health professionals often spoke of personality traits in mothers and emotional outbursts that could cause a mother's milk to go bad, making the baby ill, or interrupting milk flow and feeding. When such beliefs were confirmed or even suggested by doctors, they became legitimated as medical fact, further condemning certain maternal subjects as a risk needing to be clinically managed.

The cuarenta dias that begins in utero establishes a bond between mother, infant and community. The extended confinement and intense support it offers have a positive effect on not just the mental and physical wellbeing of the new mothers I spoke to but also on the success of continuous breastfeeding. Even when women gave birth in the hospital, which commonly resulted in surgery, the cuarenta dias formed an essential part of healing and initial processing of any experienced trauma. It provided them with an opportunity to breathe and bond with their infant before facing the world. The ways in which this community resource was crucial to health of women and new-borns, despite being prevalent, was often overlooked by hospital providers. Of course, this nurturing reminds us that even for women in the neighborhood, the regular use of herbs and diet rules suggests that a mother's milk is not always deemed enough strength and quality alone for a healthy infant. This sense of inadequacy may be a gradual effect of medical discourse, particularly in terms of strength and quality of milk, or it may be associated with women's perceptions of their own impoverishment (as noted by Scheper-Hughes). Nevertheless, these perceptions are turned, in neighborhood regimes of care, into remediable problems. The ways in which families manage new mothers during the postpartum period demonstrates that conundrums are always more complicated than unitary causes and effects would have it.

Often the question of breastmilk being inadequate were framed as problems of quantity, not quality. Women talked about how milk might not be enough to fill the infant or that it is too watery. These descriptions sometimes mirror the types of things that women are told by health professionals. Still, women do not blindly follow public health advice, and they take note of what is relevant to their existing beliefs and adopt messages that legitimise problems they may experience in establishing or maintaining breastfeeding. Collectively, women are confident enough to reject explanations that do not fit in with their own nurturing beliefs, which may in and of itself be an artefact of their mistrust of health professionals. Still, the misinformation handed out to new mothers by doctors persists in day to day practice and 
gradually seeps into shared social understanding. Consequently, the accepted notion that generations of mothers in a family have valid expertise in these matters diminishes day by day. Carlita's case demonstrates how, although a mother's milk is susceptible to contamination, it can be made good again according to women's expertise. The emphasis for breastfeeding is on the bodily and sensual connection and temporal continuity between mother and infant via breast, mouth, and milk -all of which are paramount for the wellbeing of both parties.

\section{Conclusion}

My research on postpartum practices and early infant feeding in Southeast Mexico raises important questions about who determines the rules of breastfeeding and who makes the dayto-day decisions about how breastfeeding happens. Carlita's case illustrates how relationships among women (as patients and mothers), communities, doctors, and larger institutions form a complex web of negotiating competing ideas about risk. Doctors' attitudes to a mother's milk and body appear contradictory and disjointed at best as they are translated through the prism of illness and disease. Doctors' actions often clash with the public health message that breastmilk and feeding are the optimal source of nutrition for new-borns. Consequently, they fail to recognise local beliefs and practices that understand breastfeeding as a complex practice, inseparable from beliefs of nurturing and person-making. For many doctors in Mexico, risk is framed as a danger to life. Maternal bodies and women's behaviour in neighborhoods like that of Carlita are thought to embody potential risk and are therefore understood by doctors to be inherently problematic. According to this risk-danger model, behaviour must be modified for the risk to be lessened. The problem is that women like Carlita cannot change these aspects of who they are. They can, however, nurture themselves sufficiently to provide healthy breastmilk.

For the women in the neighborhood, medical threats of danger are weighed up against the risk of breaking the bond between a mother and child that is formed by breastfeeding, and the notion that milk can be made better again with intervention. In this way, ideas about agency appear through the competing ideas about contamination, risk, uncertainty, and ultimately what it means to be a good mother. While the ethnographic material discussed in the present article does not offer a conclusive answer to the disconnection between universal breastfeeding goals and local interpretations, it does demonstrate that breastfeeding is a choice that is often based upon caregiving norms and shared ideas about personhood rather than out of a sense of obligation to state rhetoric If breastfeeding programmes are to be 
successful, policymakers should take into account the fluidity at play within the multifactorial eco-system of nurturing and women's own ability to maintain milk flow despite external threats. Policy must avoid treating women as passive recipients of biomedical messages. At a global level we can learn from the ways in which maternal bodies and the substances they produce are inseparable from the broader sense of what it means to be a human.

\section{References}

Atkin, Lucille. C., Kimberli Keith-Brown, Martha W. Rees and Paola Sesia. 2015. Iniciativa de la Fundacion MacArthur para Promover la Partería en México: Informe de resultados de la linea de base. Mexico: Asociación Mexicana Partería [accessed 05/08/2018] https://www.macfound.org/media/office_article_pdfs/Linea_de_Base_Parteria_VERS ION_COMPLETA_EN_ESP.pdf

Ausona Bieto, Marta, Serena Brigidi, and Laura Cardús Font. 2017. "Lactancias, capital y soberanía alimentaria. La falaz escasez de la leche humana." Dilemata (25):135-142. [Accessed 10/17/2018] https://www.dilemata.net/revista/index.php/dilemata/article/view/412000138

Bringas, Ángeles Sánchez, Sara Espinosa, Sara Espinosa Islas, Claudia Ezcurdia, and Edna Torres. 2004. "Nuevas maternidades o la desconstrucción de la maternidad en México." Debate Feminista 30 (1):55-86. doi: 10.2307/42624831.

Bueno-Gutierrez, Diana, and Caroline Chantry. 2015. "Using the Socio-ecological Framework to Determine Breastfeeding Obstacles in a Low-Income Population in Tijuana, Mexico: Healthcare Services." Breastfeeding Medicine 10 (2):124-131. doi: 10.1089/bfm.2014.0109.

Carrillo, Héctor, and Katherine E Bliss. 2007. "Nuevas direcciones: Sexuality, politics, and reproductive health in Mexico." Sexuality Research \& Social Policy 4 (3):1-5. doi: 10.1525/srsp.2007.4.3.1.

Castro, Arachu. 2004. "Contracepting at Childbirth: The integration of reproductive health and population policies in Mexico." In Unhealthy Health Policy: A Critical Anthropological Examination, edited by Arachu Castro and Singer Merrill. Plymouth Altamira.

Cevese, Rossella. 2015. "Who Knows if One Day, in the Future, They Will Get Married...?": Breastmilk, Migration, and Milk Banking in Italy. In (Eds.), Ethnographies of breastfeeding: Cultural contexts and confrontations, edited by T. Cassidy \& A. E1 Tom, pp. 99-109. London: Bloomsbury Academic.

Colombara, Danny V., Bernardo Hernández, Marielle C. Gagnier, Casey Johanns, Sima S. Desai, Annie Haakenstad, Claire R. McNellan, Erin B. Palmisano, Diego RíosZertuche, Alexandra Schaefer, Paola Zúñiga-Brenes, Nicholas Zyznieuski, Emma Iriarte, and Ali H. Mokdad. 2015. "Breastfeeding Practices among Poor Women in Mesoamerica." The Journal of Nutrition 145 (8):1958-1965. doi: 10.3945/jn.115.213736. 
Cusicanqui, Silvia Rivera. 2012. "Ch'ixinakax utxiwa: A Reflection on the Practices and Discourses of Decolonization." South Atlantic Quarterly 111 (1):95-109. doi: 10.1215/00382876-1472612.

de la Rosa, Leticia, and Adolfo Gabriel Hernández. 2000. "Capacitación sobre lactancia materna al personal de enfermería del Hospital General de México." Salud Pública de México 42 (2). [Accessed 10/02/2018] http://www.redalyc.org/articulo.oa?id=10642207

Dettwyler, Katherine A.1988. "More Than Nutrition: Breastfeeding in Urban Mali." Medical Anthropology Quarterly 2 (2):172-183. doi: 10.1525/maq.1988.2.2.02a00060.

Dixon, Lydia. 2015. Obstetrics in a Time of Violence: Mexican Midwives Critique Routine Hospital Practices. Medical Anthropology Quarterly, 29(4), 437-454. doi: 10.1111/maq.12174

Douglas, Mary. 2002 (1966) Purity and Danger: an analysis of concepts of pollution and taboo. London: Routledge.

Douglas, Mary. 1990. "Risk as a Forensic Resource." Daedalus 119 (4):1-16. doi: $10.2307 / 20025335$.

ENSANUT. 2012. Encuesta Nacional de Salud y Nutrición 2012. Resultados por Entidad Federativa: Chiapas. México: Instituto Nacional de Salud Publica. [Accessed 08/16/2016] http://ensanut.insp.mx/informes/ENSANUT2012ResultadosNacionales.pdf.

Faircloth, Charlotte. 2013. Militant Lactivism: infant feeding and maternal identity work in the UK and France. New York: Berghahn Books.

Falls, Susan. 2017. White Gold: Stories of Breast Milk Sharing: UNP: Nebraska.

Farmer, Paul.1988. "Bad Blood, Spoiled Milk: Bodily Fluids as Moral Barometers in Rural Haiti." American Ethnologist 15 (1):62-83. [Accessed 05/21/2017] http://www.jstor.org/stable/645486

Freyermuth, María Graciela, José Alberto Muños, and María del Pilar Ochoa. 2017. "From therapeutic to elective cesarean deliveries: factors associated with the increase in cesarean deliveries in Chiapas." International Journal for Equity in Health 16:88. doi: 10.1186/s12939-017-0582-2.

Garita Edelen, Alexandra, Brando Flores Perez, and Ángel Ruiz Tovar. 2016. Embarazo y Maternidad en la Adolescencia: Estado de Madres en México. México: Save the Children.

González de Cosío, Teresita, Leticia Escobar-Zaragoza, Luz Dinorah González-Castell, and Juan Ángel Rivera-Dommarco. 2013. "Prácticas de alimentación infantil y deterioro de la lactancia materna en México." Salud Pública de México 55: S170-S179. [Accessed 05/20/2016] http://www.scielosp.org/scielo.php?script=sci_arttext\&pid=S0036$\underline{36342013000800014 \& \text { nrm }=\text { iso }}$ 
Gottlieb, Alma.1989. ""Rethinking Female Pollution: The Beng of Cote D'Ivoire."" Dialectical Anthropology 14 (2):65-79.

Guerrero, ML, RC Morrow, JJ Calva, H Ortega-Gallegos, SC Weller, GM Ruiz-Palacios, and AL Marrow.1999. "Rapid ethnographic assessment of breastfeeding practices in periurban Mexico City." Bulletin - World Health Organisation 77:323-330. [Accessed 04/17/2018] http://www.who.int/bulletin/archives/77(4)323.pdf

Gutmann, M.C. 2009. "Planning Men Out of Family Planning." Sexualidad, Salud y Sociedad (1):104-124. [Accessed 03/27/2017] http://www.epublicacoes.uerj.br/index.php/SexualidadSaludySociedad/article/view/16/130

MacKenzie Bryers, Helen, and Edwin van Teijlingen. 2010. "Risk, theory, social and medical models: A critical analysis of the concept of risk in maternity care." Midwifery 26 (5):488-496. doi: http://dx.doi.org/10.1016/j.midw.2010.07.003

Maher, Vanessa. 2015. "Women and Children First? Gender, Power, and Resources, and their Implications for Infant Feeding." In Ethnographies of Breastfeeding, edited by Tanya Cassidy and Abdullahi El Tom. London: Bloomsbury Academic.

Maher, Vanessa. 1995. Anthropology of Breastfeeding Natural Law or Social Construct. 2nd ed. Vol. 3, Cross-Cultural Perspectives on Women: Berg.

Mathews, Anne. 2015. "Impersonal Perspectives" on Public Health Guidelines on Infant Feeding and HIV in Malawi." In Ethnographies of Breastfeeding, edited by Tanya Cassidy and Abdullahi El Tom. London: Bloomsbury Academic

McFadden, Alison, Frances Mason, Jean Baker, France Begin, Fiona Dykes, Laurence Grummer-Strawn, Natalie Kenney-Muir, Heather Whitford, Elizabeth Zehner, and Mary J. Renfrew. 2016. "Spotlight on infant formula: coordinated global action needed." The Lancet 387 (10017):413-415. doi: 10.1016/S0140-6736(16)00103-3.

Mead, Margaret. 1970. Working Mothers: And Their Children. Childhood Education, 47(2), 66-71. doi:10.1080/00094056.1970.10727226

Murray de López, Jenna. 2015. "Conflict and Reproductive Health in Urban Chiapas: Disappearing the Partera Empírica." Anthropology Matters 16 (1). [Accessed 10/10/2018] https://www.anthropologymatters.com/index.php/anth matters/article/view/339/570

Murray de López, Jenna. 2018. "When the scars begin to heal: narratives of obstetric violence in Chiapas, Mexico." International Journal of Health Governance 23 (1):6069. doi: doi:10.1108/IJHG-05-2017-0022

Murray de López, Jenna. Forthcoming. Becoming (M)Other: Transitions and Life-Course in Southern Mexico (working title), Fertility Reproduction and Sexuality. Oxford: Berghahn Press.

Murray de López, Jenna, and Cristina Alonso. 2018. "Riesgo o Aliento: El caso de una Casa de Partos." In Los caminos para parir en México en el siglo XXI Experiencias de investigación, vinculación, formación y comunicación, edited by Graciela Freyermuth, 142-149. Mexico: CIESAS 
Murray de López, Jenna, and Cristina Alonso. in press 2019. "Quality over quantity: the true cost of improving maternal mortality in Mexico " In Anthropologies of global maternal and reproductive health: From policy spaces to sites of practice., edited by Lauren $\mathrm{J}$ Wallace, Margaret Macdonald and Katerini T. Storeng. US: Springer.

Navarro Estrella, Manuel, María Ximena Duque López, and Juan Antonio Trejo y Pérez. 2003. "Factores que influyen en el abandono temprano de la lactancia por mujeres trabajadoras." Salud Pública de México 45 (4). [Accessed 10/10/2018] http://www.redalyc.org/articulo.oa?id=10645406

OECD. 2015. Measuring Wellbeing in Mexican States: Executive Summary In Measuring Well-Being in Mexican States, edited by Secretary General OECD. Paris: OECD. [Accessed 11/09/2017] http://www.oecd.org/gov/regional-policy/Mexican-StatesHighlights-English.pdf

Palmquist, Aunchalee E. L., and Kirsten Doehler. 2014. "Contextualizing online human milk sharing: Structural factors and lactation disparity among middle income women in the U.S." Social Science \& Medicine 122:140-147. doi: https://doi.org/10.1016/j.socscimed.2014.10.036.

Pérez-Escamilla, Rafael, Sofia Segura-Millán, Ernesto Pollitt, and Kathryn G. Dewey. 1993. "Determinants of lactation performance across time in an urban population from Mexico." Social Science \& Medicine 37 (8):1069-1078. doi: http://dx.doi.org/10.1016/0277-9536(93)90441-6.

Pérez-Escamilla, Rafael. 2003. "Breastfeeding and the nutritional transition in the Latin American and Caribbean Region: a success story?" Cadernos de Saúde Pública 19:S119-S127.

Reyes-Foster, Beatriz M, Shannon K Carter, and Melanie Sberna Hinojosa. 2015. "Milk Sharing in Practice: A Descriptive Analysis of Peer Breastmilk Sharing." Breastfeeding Medicine 10 (5):263-269. doi: 10.1089/bfm.2015.0009.

Rollins, Nigel C., Nita Bhandari, Nemat Hajeebhoy, Susan Horton, Chessa K. Lutter, Jose C. Martines, Ellen G. Piwoz, Linda M. Richter, and Cesar G. Victora. 2016. "Why invest, and what it will take to improve breastfeeding practices?" The Lancet 387 (10017):491504. doi: 10.1016/S0140-6736(15)01044-2.

Romano, Mattea, Alessandra Cacciatore, Rosalba Giordano, and Beatrice La Rosa. 2010. "Postpartum period: three distinct but continuous phases." Journal of Prenatal Medicine 4 (2):22-25. [Accessed 08/16/2017] https://www.ncbi.nlm.nih.gov/pmc/articles/pmid/22439056/?tool=EBI

Sacco, Lisa M., Laura E. Caulfield, Joel Gittelsohn, and Homero Martínez. 2006. "The Conceptualization of Perceived Insufficient Milk Among Mexican Mothers." Journal of Human Lactation 22 (3):277-286. doi: 10.1177/0890334406287817.

Santiago, Rosario Valdez, Luz Arenas Monreal, Anabel Rojas Carmona, and Mario Sánchez Domínguez. 2018. "'If we're here, it's only because we have no money..." discrimination and violence in Mexican maternity wards." BMC Pregnancy and Childbirth 18 (1):244. doi: 10.1186/s12884-018-1897-8. 
Scheper-Hughes, Nancy.1985. Culture, Scarcity, and Maternal Thinking: Maternal Detachment and Infant Survival in a Brazilian Shantytown. Ethos, 13(4), 291-317. doi:10.1525/eth.1985.13.4.02a00010

Scheper-Hughes, Nancy. 1993. Death without weeping: The violence of everyday life in Brazil. Berkeley: University of California Press.

Secretaría de Salud. 2014. Estrategia Nacional de Lactancia Materna 2014-2018. edited by Secretaria de Salud. Mexico. [Accessed on 11/24/2017] http://www.gob.mx/cms/uploads/attachment/file/75383/ENLM_2014-2018.pdf

Singer, Elyse Ona. 2017. "Lawful Sinners: Reproductive Governance and Moral Agency Around Abortion in Mexico." Culture, Medicine, and Psychiatry. doi: 10.1007/s11013017-9550-y.

Smith-Oka, Vania. 2013. Shaping the motherhood of indigenous Mexico. Nashville: Vanderbilt University Press.

Soler, Elena. 2017. "Bancos de leche, parentesco de leche e Islam. Restricciones alimentarias entre la población infantil en Barcelona." Dilemata (25):109-119. [Accessed on 10/17/2018] https://www.dilemata.net/revista/index.php/dilemata/article/view/412000136

Tomori, Cecília, Aunchalee E. L. Palmquist, and Elizabeth A. Quinn. 2017. Breastfeeding: New Anthropological Approaches. London: Routledge.

Tomori, Cecília. 2015. Nighttime breastfeeding: an American cultural dilemma. New York: Berghahn Books.

Valeri, Valerio. 2000. The Forest of Taboos: Morality, Hunting, and Identity among the Huaulu of the Moluccas. Madison: University of Wisconsin Press

Van Esterik, Penny, and Richard A. O'Connor. 2017. The Dance of Nurture: negotiating infant feeding. New York: Berghahn Books.

Van Esterik, Penny. 1988. The insufficient milk syndrome: biological epidemic or cultural construction. In Women \& Health Cross Cultural Perspectives, edited by Patricia Whelehan, Granby MA: Bergin and Garvey.

Van Esterik, Penny. 1989. Beyond the breast-bottle controversy. New Brunswick NJ: Rutgers University Press.

Van Hollen, Cecilia. 2011. "Breast or Bottle? HIV-Positive Women's Responses to Global Health Policy on Infant Feeding in India." Medical Anthropology Quarterly 25 (4):499518. doi: 10.1111/j.1548-1387.2011.01182. $\mathrm{x}$.

Victora, Cesar G., Rajiv Bahl, Aluísio J. D. Barros, Giovanny V. A. França, Susan Horton, Julia Krasevec, Simon Murch, Mari Jeeva Sankar, Neff Walker, and Nigel C. Rollins. 2016. "Breastfeeding in the 21st century: epidemiology, mechanisms, and lifelong effect." The Lancet 387 (10017):475-490. doi: 10.1016/S0140-6736(15)01024-7.

Vidal, Francesca Sanz. 2017. "Lactivismo como movimiento de resistencia:(re) acciones lactivistas en contextos urbanos mexicanos." Dilemata (25):239-250. [Accessed 
$10 / 10 / 2018]$

https://www.dilemata.net/revista/index.php/dilemata/article/view/412000145

Notes

\footnotetext{
' Nancy Scheper-Hughes documented at length the somatization of scarcity amongst the urban poor in Brazil, identifying how women internalize the aforementioned socio-political barriers to breastfeeding and "like so many elsewhere...explain their failure to breasted in terms of "insufficient milk" '(1993:317).

ii From here forwards, the colloquial cuarenta dias is used to adhere to the type of convalescence rather than a specific number of days.
} 